\title{
Introduction: The Persistence of Dwelling
}

\section{Grant Farred and Alfred J. Lopez}

Journal of French and Francophone Philosophy - Revue de la philosophie française et de langue française, Vol XXV, No 1 (2017) 1-9.

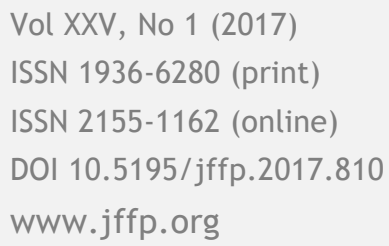

\section{(oc) EY-NO-ND}

This work is licensed under a Creative Commons Attribution-Noncommercial-No Derivative Works 3.0 United States License.

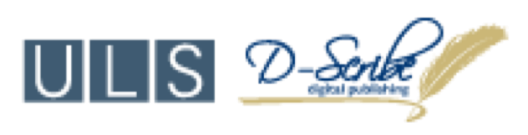

This journal is operated by the University Library System of the University of Pittsburgh as part of its D-Scribe Digital Publishing Program, and is co-sponsored by the University of Pittsburgh Press 


\title{
Introduction
}

The Persistence of Dwelling

\author{
Grant Farred \\ Cornell University
}

Alfred J. Lopez

Purdue University

These buildings house man. He inhabits them and yet he does not dwell in them, when to dwell means merely that we take shelter in them.

Martin Heidegger, "Bauen Wohnen Denken”

Residents of fifteen houses had been ordered to leave their little neighborhood on the edge of town. Twenty four

hours, they were told, or else. "Else" meaning "die."

Toni Morrison, Home

The decision to dwell, as Toni Morrison reveals in her novel Home, is always potentially fatal. To dwell is not merely to live in a house; a home might be a dwelling, but there is no guarantee that the "home" makes dwelling possible, that it does anything more than shelter humans. In fact, occupying a building has very little to do with dwelling. To dwell, on the other hand, is to come fully into oneself, to have thought oneself assiduously, exhaustively, in relation to that self. In this sense being only becomes possible in and through dwelling, in the act of making of the house or home a dwelling. To live in a house that does not permit dwelling due to whatever mechanism of oppression, whether political or cultural disenfranchisement or outright colonization or occupation, is to be homeless in a philosophical sense. Such a building stands as the visible index of that which suppresses or disables or forbids dwelling - the very emblem of homelessness.

In Home Morrison identifies dwelling through an exceptional attachment to what might be named the living history of a family's rootedness. Only one of the characters in Morrison's Home refuses to leave

Journal of French and Francophone Philosophy | Revue de la philosophie française et de langue française Vol XXV, No 1 (2017) | www.jffp.org | DOI 10.5195/jffp.2017.810 
"their little neighborhood on the edge of town," despite knowing full well the cost of his decision. This character, an "elderly man named Crawford," chooses instead to face the white mob in his small Georgia town, to be beaten to death, bound to the "oldest magnolia tree in the county." ${ }_{2}$ His former neighbors sneak back and bury him beneath that magnolia tree, which Crawford claimed his great-grandmother had planted. The tree, his terrified neighbors speculate, is the reason he could not leave: he was bound to it, bound by family history, bound by a love of that tree. Crawford's choice is consistent with dwelling as what Heidegger calls volkstümlich, traditions that define individuals and peoples and that are, necessarily, steeped in blut [blood]. This blut in turn is what binds individuals to both a shared tradition and the land that both nurtured and maintains it. The systematic disenfranchisement or marginalization or, as in Crawford's case, extermination of those who would otherwise dwell thus constitutes a denial of dwelling itself, the most visible marker of the oppressor's violence.

Thinking through $20^{\text {t- }}$ and $21^{*-c e n t u r y}$ fiction and film, this special issue casts in a postcolonial and global frame Heidegger's question: What does it mean to dwell? More precisely, how do contemporary narratives address the question of dwelling? The epigraph from Heidegger that opens this essay would not have us confuse dwelling with merely inhabiting a space; to dwell in such spaces must mean more than "merely that we take shelter in them" (Heidegger 348). ${ }^{3}$ Likewise, and like Morrison's Crawford, this special issue wants to think how to distinguish between occupying a house and truly dwelling.

This distinction between occupying a given space and identifying with a place is inextricable from even the most ancient civilizations, well

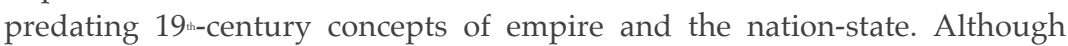
Ernest Renan's 1882 definition of the nation famously distinguishes it from the "republics, municipal kingdoms, confederations of local republics and empires" of Western antiquity, even his dismissive description of "Egypt, China, and ancient Chaldea" as "flocks led by a Son of the Sun or by a Son of Heaven" concedes the self-identification of individuals with community and place. The emergence of dwelling as an indispensible part of both individual and collective consciousness and identity paradoxically coincides with its first great crisis under colonialism, and has become simultaneously more cherished and more besieged since the rise of modern imperialism. Empire brought unprecedented complexity to notions of home, dwelling, and belonging as it produced untold millions of diasporic and internally deracinated subjects, as well as the masses of settlers and voluntary occupiers required to establish and maintain it. Since the late $20^{\text {th }}$ century the rise of globalization has further threatened traditional concepts of the nation and nationalism, but has neither lessened the desire to dwell or slowed the pace of uprooted and displaced individuals and peoples, a fact to which the ongoing global crisis of immigration amply testifies.

Journal of French and Francophone Philosophy | Revue de la philosophie française et de langue française Vol XXV, No 1 (2017) | http://www.jffp.org | DOI 10.5195/jffp.2017.810 
The Heideggerian notion of dwelling, of course, finds itself rethought, re-envisioned and repurposed for the particular politics of the postcolonial moment; it becomes "different," in Derrida's sense, in the postcolonial. We can see this postcolonial rethinking of dwelling via the work of thinkers such as Said, who presents the Orient as the space and time of the Other subjected to such violence as to draw the very notion of dwelling into question.5 Heidegger shares this political concern, but of course with distinctly different preconceptions. The post-World War II argument for dwelling is complicated and threatened, Heidegger insists, by the specter of nuclear disaster; given the shared historical moment (the imminent end of European colonial dominance), this makes Heidegger's view, if not entirely of a piece with the postcolonial agenda, then at least commensurate with it. This issue of the precarity of life (in Judith Butler's terms) of course returns to us, retooled for postcolonial use, in the work of Agamben, for whom the specter of the camp and zoe and bios articulates itself again, not simply in the camp's preeminent construct, but more pressingly in the bare life that is postcoloniality. ${ }^{6}$ The question then becomes: Is the promise-filled (if difficult to achieve) prospect of dwelling possible-that is, thinkable-in the postcolonial? Or should dwelling be the first ground-the absolutely nonnegotiable first demand-for thinking the postcolonial?

It is thus not to the oldest identifications of antiquity or the mass displacements of more recent centuries that this Special Issue directs its focus, but to the struggles of individuals in our own time. It is Crawford's magnolia tree, Heidegger might suggest, that makes of his smalltown Georgia house a dwelling. Because it is a dwelling, because it is more than just a place to live, because it is the place where he can come into being, Crawford decides to face death in his dwelling even as his neighbors flee from the white vigilantes. He is certain that death is coming, is fully aware that he will die violently; but it is more important for Crawford to dwell until death, to dwell in death, than to live in some other building. Although he knows he may be safe elsewhere, dwelling will no longer be possible.

In this way Home continues Morrison's preoccupation with dwelling, perhaps first glimpsed in Beloved's 124 Bluestone Road, then in Paradise's convent and the towns of Ruby and Paradise. Morrison, of course, is not the only author who thinks dwelling. One could, for example, offer David Malouf's oeuvre, in which the land in its entirety functions as that colonized site, that place of intense violence, that is unfit for dwelling precisely because of the violence colonialism done to the Aboriginal community. We may also think of Peter Carey's garret-like spaces, or V.S. Naipaul's A House for Mr. Biswas or the haunted house that is Shani Mootoo's Cereus Blooms At Night; or the inhospitable, unhappy, wooded English suburban outpost that is David Mitchell's wonderfully melancholy Black Swan Green. Recent American literature has also produced powerful meditations on home and dwelling, from the intense identifications of Junot Díaz's and Louise

Journal of French and Francophone Philosophy | Revue de la philosophie française et de langue française Vol XXV, No 1 (2017) | http://www.jffp.org | DOI 10.5195/jffp.2017.810 
Erdrich's characters with, respectively, Paterson NJ and the ancestral Ojibwe lands of North Dakota, to the deracinated protagonists of Dave Eggers's What Is The What and Zeitoun, to Chris Ware's meditation on the history of a century-old Chicago apartment building — and the many people who lived, dwelled, and died in it-in his landmark graphic novel Building Stories. ${ }^{9}$ Each of these texts problematizes concepts of dwelling in a global age, offering respective vistas into the present complexities of this oldest of human ideas. If, as Heidegger contends, dwelling requires attachment to a place we may call "home" - and thus to the corresponding customs and ways of being-inthe-world-then we can read in these and many other such works the stakes, the hopes and fears, that come with such attachment to places. The literature of dwelling narrativizes the persistence of dwelling, of the desire to dwell; it pursues Heidegger's questions in settings that unsettle dwelling, that threaten to render it precarious, perhaps impossible. But the desire, the imperative to dwell, persists.

If, as Lacan reminds us, desire is the subject's entry into the symbolic - if it is, in fact, the subject's originary cue to speak-that speaking subject inevitably articulates desire in the form of a demand. This in turn invokes a nomenclature, a language of dwelling, that encompasses but also transcends that of sovereignty or ownership or rights. Put another way: Who, at this moment in our history, is in a position to demand dwelling, and from whom? What agency, lawfully or not, holds the power to grant or withhold dwelling? Although Heidegger does not pose dwelling directly in terms of a demand in "Building Dwelling Thinking," his exposition of the language of dwelling moves directly from bauen [to dwell] to "the German word Nachbar, neighbor.... he who dwells nearby." ${ }_{10}$ The rest of the paragraph especially emphasizes dwelling as an activity done with others: "ich bin, du bist mean I dwell, you dwell. The way in which you are and I am, the manner in which we humans are on the earth, is buan, dwelling." "

As we have written elsewhere, dwelling is thus immanent, not just broadly to Being, but more precisely to Being-with [Mitsein]. This dwelling as Being-with extends beyond our fellow humans to our inhabited environment, as it manifests in building [bauen]: "We do not dwell because we have built, but we build and have built because we dwell, that is, because we are dwellers." "That in turn requires not only the freedom to build [Freiheit], but the state of being at peace [Freide], because only those who can dwell in peace ("the free, das Frye") are truly free to build. The common etymology of peace [Freide] and safety—for Heidegger the German "fry means preserved from harm and danger...safeguarded"-further confirms the relation between dwelling, building, and peace. ${ }^{13}$ Where these do not coincide in a given place, where Mitsein is denied to some or all of the populace, the very act of thinking dwelling-and especially of staking a claim to dwell-requires the courage to demand it. As we have written elsewhere, all of human history, and emphatically of the 500 years after

Journal of French and Francophone Philosophy | Revue de la philosophie française et de langue française Vol XXV, No 1 (2017) | http://www.jffp.org | DOI 10.5195/jffp.2017.810 
Columbus, consists of individuals and peoples making such demands, of dwellings disrupted, destroyed, demanded, sometimes achieved, but too often denied. ${ }^{14}$

Each of the essays collected here presents one or more flashpoints or

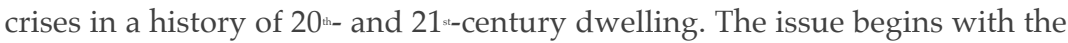
provocative opening line of Grant Farred's essay "Letting-be: Dwelling, Peace and Violence in Ngugi wa Thiong'o's Petals of Blood": "It is dwelling that allows mortals to initiate themselves in time and space." This sentence serves as Farred's point of departure for an exploration of how the fictional characters that populate Ngugi's postcolonial Kanya struggle mightily with the task of "initiating themselves in time and space," specifically in terms consistent with Heidegger's fourfold (earth, sky, mortals, and "divinities"). The essay thus casts Ngugi's romantic and rural-and thus deeply Heideggerian-vision as the crux of the characters' struggle to dwell. The obstacles that prevent Ngugi's villagers from dwelling in a modernizing postcolonial Kenya-or put another way, their inability or unwillingness to dwell in this new emergent environment-fuels the rising violence and tension that leads inexorably to a choice: between a Heideggerian dwelling, in peace with the fourfold, and a different, and profoundly ambivalent, existential state that Farred calls "letting-be." This "letting-be" is not dwelling in the Heideggerian sense of an transcendent, immersive oneness with the earth, but a more precarious acceptance of the "polyvalent" nature (Farred's term) of a life lived in an ascendant modernity that eschews the values of the fourfold. This "letting-be," in Farred's terms, "presupposes a radical openness to the fourfold - to the world - so that dwelling is best recognized as an intense understanding of how to be in the world, of what it means to be." This is a state of dwelling that strives for peace, yet recognizes the upsurge of violence that accompanies-perhaps even stands as the price of-any such peace in a polyvalent society. It is an essay, in short, that responds otherwise to the question of whether dwelling remains a possibility at all in such an inauspicious, portentous time-where violence looms, peace is always, at best, precarious.

Nicola Tutek's “Dwelling in the Apocalypse: Capitalist Modernity, Antimodernism, Zombies" shares and extends Farred's reading of Heideggerian dwelling as a desire for peace as, Tutek's words, "a condition of possibility of the escape from modernity's plight." The essay's larger agenda is a reading of Heideggerian dwelling as a profoundly antimodernist critique, which Tutek unfolds via a series of narrowing points of analysis. These proceed through an overview of the narratives of apocalypse that exposes a shared "eschatological anxiety" toward modernity andmore importantly for Tutek's purposes-a latent desire that implicitly emerges in apocalypse's potential erasure and rebooting of civilization: the end as new beginning, "but at the price," Tutek notes, "of a wholesale abandonment of modernity." Tutek further narrows his focus to the zombie

Journal of French and Francophone Philosophy | Revue de la philosophie française et de langue française Vol XXV, No 1 (2017) | http://www.jffp.org | DOI 10.5195/jffp.2017.810 
apocalypse as "the preferred apocalyptic scenario of the post-Cold War era," less a cautionary tale (as it perhaps functioned in earlier incarnations) than a collective anti-modernist fantasy. The zombie apocalypse's greatest advantage over competing end-of-the-world scenarios, consistent with the Heideggerian romance of dwelling, is its efficacy as what Peter Paik calls "an extended thought experiment about the reconstitution of community life under conditions of severe privation and perpetual danger." ${ }_{15}$ The latter half of Tutek's essay reads serial TV program The Walking Dead as precisely just such a "thought experiment," one that moves well beyond its putative main attractions (zombies and post-apocalyptic survivalism) into a extended meditation on the possibilities for human dwelling in a markedly antimodern and post-capitalist world- "not as a punishment," as Tutek explains, "but as a redemption."

Through its insouciant social history of beards, Russell Cobb's "The Bearded Ones: Dwelling in a History of Radicalism, Authenticity, and Neoliberalism" casts the previous essays' critiques of the romance of Heideggerian dwelling in a trenchantly postmodern mode. Cobb piquantly exposes both the beard's apparent "disdain for the artifices of modernity, marketplace, and utilitarianism" and its rendering, via its symbolic overdetermination, as "a symbolic gesture toward an ahistorical authenticity" that belies its own eschatological anxieties of dwelling in a global age. The essay pursues this dual examination of the beard's bid for authenticity and its eventual commodification as cultural and fashion accessory through a condensed history of its significations, lingering tellingly on the figure of the bearded radical/rebel and its successive appropriations. Key to Cobb's genealogy are the heteronormative sexual mythology of the Castro-era barbudo and that figure's symbolic overdetermination by the Whitmanesque-via-Lorca "queer beard," a untenable binary brought to crisis by Ginsburg's beardedness in revolutionary Cuba. What was, for Cobb, arguably the apotheosis of $20^{\text {th- }}$ century beardedness has since devolved under neoliberalism to a marketing ("branding") tool, one that remains richly suggestive of an anti-modern authenticity that has lost what may once have been any (univocal) significatory power (e.g., the "hipster" or "lumbersexual" beard). What was, in effect, once the hallmark of a radical, ruralized, masculine authenticity stands now as what Cobb aptly calls bodily "green-screens" that any man can build, but in which none can really dwell.

Anthony Ramos grounds his essay, "Sketching an Ontography of La Mara Salvatrucha: Radical Homelessness and Postglobal Subjects," in the lived experience La Mara, a once LA-based gang of Honduran immigrants that has morphed into an international crime cartel-arguably the world's first globalized gang. But in the larger ontographic logic of Ramos's essay, the signifier "gang" is prefigured by an entire genealogy of such constructs-the "born criminal," the "outlaw," the "rebel," Marx's

Journal of French and Francophone Philosophy | Revue de la philosophie française et de langue française Vol XXV, No 1 (2017) | http://www.jffp.org | DOI 10.5195/jffp.2017.810 
"lumpen" - that states have deployed to essentialize the criminal and position him beyond the pale, beyond any possibility of dwelling within modernity. For La Mara, it is the state, in its power to discursively "fix" them as undesireables, which holds the power to deny dwelling. Legislation such as California's STEP (Street Terrorism Enforcement and Prevention) Act of 1988 affirms that gangs have no place in the neoliberal state; their very ability, as Ramos notes, "to assemble and, in Heideggerian terms, dwell within a community is in-and-of-itself a threat to the state." The essay continues its ontographic reading that encompasses not only Heidegger's formulations of dwelling but Marx's early but definitive characterization of the lumpenproletariat-that sector of the population he considered beyond the reach of redemption through class struggle. But Ramos also reads La Mara as a unique challenge to the new global order, because they owe their existence and growth to the very neoliberal policies intended to remove them from a globalizing Los Angeles not only through domestic legislation but also via deportation-thus enabling La Mara's spread as an international rogue organization. Despite La Mara's metastacization, they remain, in his reading, among those postglobal discontents targeted for ontological and political abjection. Such peoples are, he tells us, "radically homeless because they are out-of-place, without a home in the ontologies with which we imagine and construct our social worlds." This radical homelessness, as the essay's close reading of the 2009 film Sin nombre [Nameless] reveals, is a denial of dwelling on a mass scale, an "ontological homelessness often inscribed on the bodies we find morally repulsive." By documenting the struggles of protagonists operating within a world that builds for others but not for them, director Cary Joji Fukunaga confronts viewers with the plight of other unknown millions who remain "sin nombre" (nameless), those postglobal subjects for whom dwelling is foreclosed because of a new world order that defines the parameters of the human precisely by parsing them as undesirable.

Ethan Mannon's "Precluded Dwelling: The Dollmaker and Under The Feet of Jesus as Georgics of Displacement" extends Ramos's analytic of radical homelessness by reading displacement, the defining characteristic of Arnow's and Viramontes's respective novels, as a denial of dwelling. Specifically, Mannon's close readings trace both the persistence of the desire to achieve rootedness - in in short, to dwell-and its impossibility, through the lens of the georgic mode, a global literary tradition defined by its rural vision of labor (as cultivation) and/as dwelling. For Mannon, however, the georgic ideal operates only ironically in Arnow's and Viramontes's modern exemplars, serving to affirm its pursuit as both worthy and doomed. Its comparative reading of an Appalachian and a Chicano text further expand this Special Issue's narrative palette, casting the desire to dwell as one that transcends racial, identitarian, and historical differences.

Journal of French and Francophone Philosophy | Revue de la philosophie française et de langue française Vol XXV, No 1 (2017) | http://www.jffp.org | DOI 10.5195/jffp.2017.810 
It is precisely through race, identity, and history that this Special Issue's closing essay, Scott Astrada's "History and Dwelling: Re-examining Race and Identity through Octavia Butler's Kindred and Paul Beatty's The Sellout," returns to our central question of dwelling in a global age. Acknowledging the urgency of reformulating the question in the absence of a totalizing postcolonial or postmodern master discourse, Astrada reframes Heideggerian dwelling through his close reading of two contemporary African-American novels that nevertheless bring broader ontological implications to bear on the (im)possibility of dwelling, not only in space, but in time. Each novel features a protagonist "attempting to find their place in the world," against the background of both a history and lived experience of slavery. At stake, as it is for so many who would dwell but cannot, is the imposition of a colonial ideology and ontology upon the subaltern, fueling the self-alienation that Astrada elegantly describes as "a blurring of the line of self and other in the very dwelling space of the subject." For Butler's Dana, this means dwelling in a space that is overdetermined by a history she is forced to relive and relearn; in Beatty's The Sellout, the protagonist, identified only as "Me," counterintuitively asserts his agency by attempting to reinstate slavery in his hometown, an act that Astrada reads as "rethinking-and seemingly discarding-notions of metaphysical essence surrounding historical identity." Each novel, in short, variously reconfigures the question of dwelling as a Being not only with-others in the present moment, but with untold numbers of others in remembered and unremembered time.

Both the essays collected here and the narratives they explore leave us in a place much akin to what Heidegger finally determines as "the plight" of dwelling: "that mortals search ever anew for the essence of dwelling, that they must ever learn to dwell." ${ }_{16}$ In Heidegger's time as in ours, the future of the possibility of dwelling is as precarious as the desire for it is persistence. "In the very depth of misfortune," Heidegger tells us, "they wait for the weal that has been withdrawn." ${ }_{17}$ It is the persistence of a perhaps impossible demand that, perhaps inexplicably, endures in the face of all obstacles.

\footnotetext{
${ }^{1}$ Toni Morrison, Home: A Novel (New York: Alfred A. Knopf, 2012), 10.

${ }^{2}$ Ibid.

${ }^{3}$ Martin Heidegger, "Building Dwelling Thinking," in Martin Heidegger: Basic Writings, ed. David Farrell Krell (San Francisco: HarperCollins, 1993), 348.

${ }^{4}$ Ernest Renan, "What Is A Nation?" in Nation and Narration, ed. Homi K. Bhabha (Abingdon: Routledge, 1990), 9.
}

Journal of French and Francophone Philosophy | Revue de la philosophie française et de langue française Vol XXV, No 1 (2017) | http://www.jffp.org | DOI 10.5195/jffp.2017.810 
${ }^{5}$ The immediate reference is to Said's seminal work Orientalism, but in this context readers may also want to see his writings on Palestine, most notably The Question of Palestine.

${ }^{6}$ See Butler Precarious Life and Agamben Homo Sacer, respectively.

${ }^{7}$ See for example Malouf's arguably best-known work, the 1993 novel Remembering Babylon, in which an English boy raised in a foreign land by aborigines struggles with questions of identity and dwelling after white settlers arrive there.

${ }^{8}$ See e.g., Carey The True History of the Kelly Gang; Naipaul A House for Mr. Biswas; Mootoo Cereus Blooms at Night; and Mitchell Black Swan Green, respectively.

9 Díaz's and Erdrich's respective recent work explores their characters' intense attachment to place-an attachment deeply beset by histories of violence and social injustice. See e.g., Díaz Drown \& Brief, and Erdrich Plague \& Round. See also Eggers What \& Zeitoun, and Ware Building.

${ }^{10}$ Heidegger, “Building Dwelling Thinking," 348.

${ }^{11}$ Ibid., 349.

12 Ibid., 350.

${ }^{13}$ Ibid., 351

${ }^{14}$ See López.

${ }^{15}$ Peter Paik, "The Gnostic Zombie and the State of Nature: On Robert Kirkman's The Walking Dead," Social Science Research Network, Aug. 19, 2011, 8.

${ }^{16}$ Heidegger, “Building Dwelling Thinking," 363.

${ }^{17}$ Ibid., 352. 